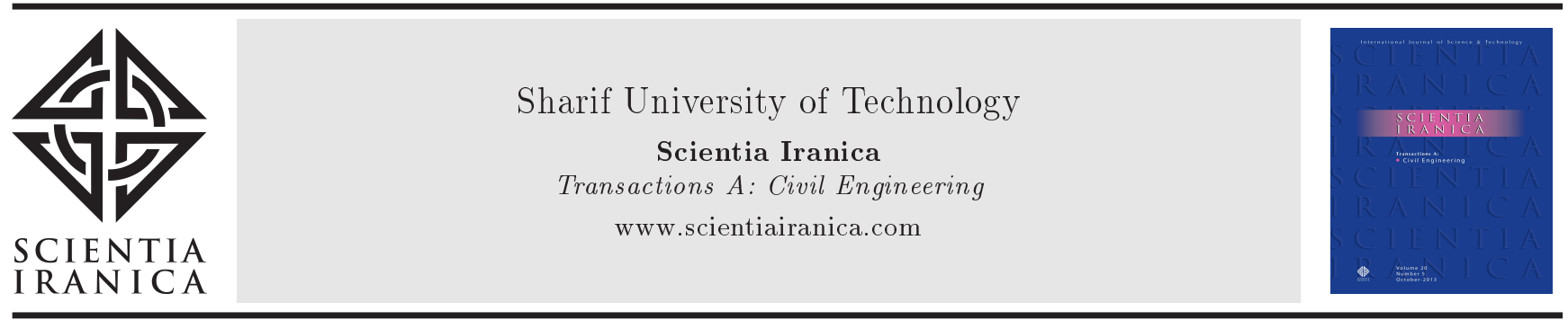

\title{
Effect of reinforcement geometry on the performance of a reduced-scale strip footing model supported on geocell-reinforced sand
}

\author{
M. Kargar and S.M. Mir Mohammad Hosseini* \\ Department of Civil and Environmental Engineering, Amirkabir University of Technology, Tehran, Iran.
}

Received 13 April 2015; received in revised form 15 September 2015; accepted 21 November 2015

\section{KEYWORDS \\ Bearing capacity; \\ Settlement; \\ Strip footing; \\ Reinforced sand; \\ Geocell geometry; \\ Physical model.}

\begin{abstract}
Geocell is an effective type of geosynthetics for improving the performance of reinforced soil foundations due to provision of lateral confinement for the infill soil. In this research, in order to study the bearing pressure-settlement response of geocellreinforced sand, a reduced-scale physical model is developed and geocells with various geometrical dimensions (height, pocket size, and width) produced from woven geotextile are used to reinforce sand bed. Strip footing model is then loaded monotonically to ultimate failure level, and the influence of geocell geometrical properties on the improvement in bearing capacity and settlement of footing is described. The results show that by increasing height and decreasing pocket size of geocell, the beneficial effect of geocell reinforcement increases substantially. For the highest geocell used in the tests at settlement level of $6 \%$, improvement in bearing capacity and percentage reduction in footing settlement are obtained as 2.1 and $48 \%$, respectively. The optimum width of geocell is determined five times the foundation width beyond which the improvement effect is negligible. It is also concluded that substituting a single layer of geocell reinforcement with 2 half-height and 4 quarter-height geocell layers results in $10 \%$ and $22 \%$ decrease in the ultimate bearing capacity, respectively.

(C) 2017 Sharif University of Technology. All rights reserved.
\end{abstract}

\section{Introduction}

Geosynthetics are extensively used to reinforce soil foundations, and geocell is one of the recent forms of geosynthetics that can be effectively applied as soil reinforcement for embankments, foundations, retaining walls, and slopes. Due to three-dimensional geometry of geocell, great lateral confinement is provided for the infill material resulting in performance improvement of the soil bed without dependence on the friction or interlocking with the infill soil. Therefore, the additional advantage of geocell makes it superior to

*. Corresponding author. Tel.: +982164543028 E-mail addresses: mohsenkargar@aut.ac.ir (M. Kargar); smmirhos@aut.ac.ir (S.M. Mir Mohammad Hosseini) other types of reinforcement inclusions in increasing the bearing capacity of foundations and embankments and reducing footing settlements. Zhang et al. [1] reviewed the main geocell layer mechanisms as lateral resistance effect, vertical stress distribution effect, and tensioned membrane effect.

Several investigations have been carried out on stress-strain behavior of geocell encased soil samples on triaxial condition (e.g. [2-5]). The results of largescale triaxial tests on samples of geocell-reinforced sand have shown that shear strength of geocell encased sand increases since an apparent cohesion is induced in the sand due to confinement while the internal friction of the infill sand remains constant [2]. The induced apparent cohesion depends on the axial strain of geocell at failure, diameter of geocell pockets, modulus of 
the geocell material, and internal friction of infill sand. Madhavi Latha et al. [6] proposed a nonlinear empirical equation to determine the stiffness of the infill sand in terms of modulus of the geocell material and stiffness of the unreinforced sand and presented a design methodology for two-dimensional numerical analysis of geocell-reinforced foundations considering the properties of equivalent geocell-sand composite material.

Several researchers have conducted laboratory tests to study the improvement effect of geocell reinforcements under vertical loading on the small-scale and large-scale physical models (e.g. [7-14]). Bathurst and Jarret [15] compared the results of large-scale model tests of geoweb and geogrid cell mattresses over soft subgrade and showed that the stiff geoweb shows a better load-settlement response. Dash et al. [16] reported optimum values of reinforcement geometry based on experimental tests on geocells made from geogrids. Sireesh et al. [17] showed that the provision of geocell mattress over clay subgrade with void can improve the performance substantially, provided that the geocell mattress extends at least a distance equal to the diameter of void. Madhavi Latha and Somwanshi [18] studied the relative performance of different forms of reinforcement (geocell, planar layers, and randomly distributed mesh elements) and concluded that geocell is the most advantageous reinforcement.

Moghaddas Tafreshi and Dawson [19] compared the improvement in bearing capacity of planar geotextiles and three-dimensional geotextiles and concluded that the geocell reinforcement system behaves much stiffer, carries greater loading, and settles less than the equivalent planar reinforcement system. Pokharel et al. [20] investigated the parameters affecting the behavior of single geocell-reinforced soil under static loading and reported that performance of geocellreinforced sand depends on the elastic modulus of the geocell. Dash [21] investigated the influence of relative density of soil and suggested that for the effective utilization of geocell reinforcement, the foundation soil should be compacted to higher density. Dash [22] concluded that the strength, stiffness, aperture size, and orientation of the ribs of geocell prepared using geogrids influence the performance of the reinforced sand foundations. Biswas et al. [23] indicated that the performance of the geocell-reinforced foundation is highly dependent on subgrade strength.

Several analytical solutions have been suggested for the load-settlement analysis of geocell reinforced soils. Mitchell et al. [24] analyzed the behavior of grid cell systems based on different modes of failure. Avesani Neto et al. [25] proposed an analytical approach to predict the bearing capacity of geocellreinforced soil by taking into account the geometric characteristics of geocell reinforcement. Moghaddas Tafreshi et al. [26] presented a simplified method for predicting settlement of circular footings on multilayered geocell-reinforced non-cohesive soils.

The extensive research carried out in the performance of geocell-reinforced sand foundations is mostly related to geocells made from geogrid or factorymade geowebs of polymeric sheets. Few investigations are performed with geocell produced from geotextiles (e.g. [19]). In addition, the effect of geometrical properties of geocell reinforcement is not thoroughly studied due to limitation in providing reinforcements with various geometrical conditions. In this research, series of experimental tests have been conducted on a reduced-scale physical model of geocell reinforced sand foundation. Geocells of different geometries are produced from strips of woven geotextile, and the effects of geocell height, pocket size, and width on the pressure-settlement response of strip footing are evaluated. The influence of substituting a single geocell reinforcement layer with two layers of halfheight and four layers of quarter-height geocell (in which height of reinforced zone is similar in all cases) is also discussed. Finally, the efficiency of variation of different geometrical properties to get the maximum performance improvement of geocell-reinforced sand is compared through a cost-benefit analysis.

\section{Laboratory model}

To investigate the pressure-settlement response of footings on geocell-reinforced sand, a reduced-scale laboratory model is developed. The general arrangement of the physical model is illustrated in Figure 1. Loading plate is a thick plate made of aluminum with $B=$ $50 \mathrm{~mm}$ in width and $L=340 \mathrm{~mm}$ in length to represent a rigid strip footing. Through sticking sand paper to the bottom of footing model rough base condition is

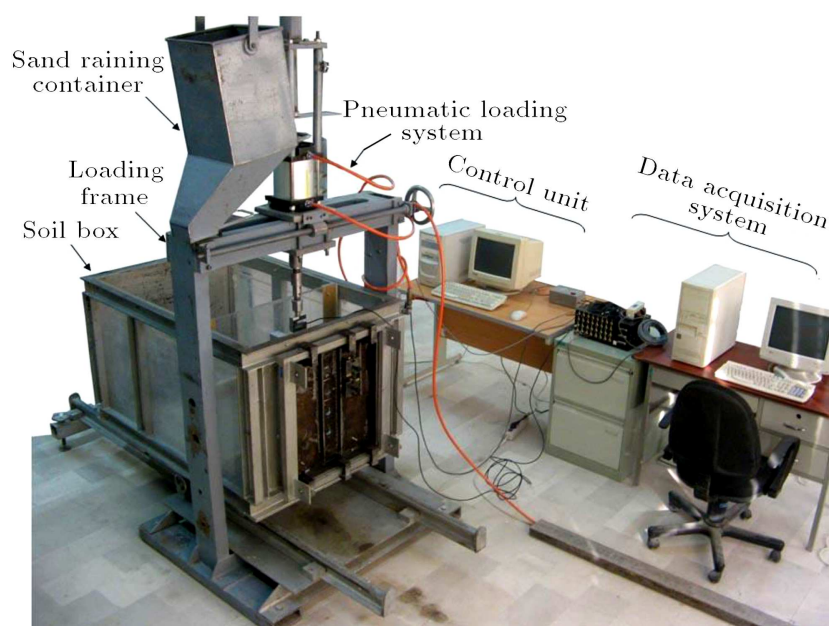

Figure 1. Photographic view of general arrangement of the physical model apparatus. 
provided for the footing. The length of soil tank is considered $800 \mathrm{~mm}(16 \mathrm{~B})$ in order to be large enough to overcome boundary effects. Observations of the soil deformation during the tests and after failure verify that side walls of the test tank do not affect the footing performance. The width of the container should be equal to the length of the footing in order to establish the plane strain conditions. However, $1 \mathrm{~mm}$ wide gap is provided to avoid any contact between the footing and side walls; as a result, soil box width is measured $342 \mathrm{~mm}$. It should be noted that the experimental setup is a modified version of the apparatus previously used by Kargar and Mir Mohammad Hosseini [27] for other research purposes. Therefore, only a limited dimension of $342 \mathrm{~mm}$ from the total $1500 \mathrm{~mm}$ length of the box shown in Figure 1 is used for the tests.

The height of the sand sample is equal to $560 \mathrm{~mm}$ which is large enough (more than 10B) to eliminate the effect of bottom boundary on the result. The side walls of the tank are made from plexiglass sheets restrained by steel frames or plates to provide rigidity of the tank. The plexiglass sheets in the sides of the tank are used to reduce the effect of friction between soil particles and tank walls, in addition to possibility of visualization of soil particles movement and failure zones during loading tests.

The sand sample in this research is prepared using the air pluviation technique to achieve uniform dense sand bed. The height and rate of raining are calibrated to obtain the desired relative density. Loading system includes a pneumatic cylinder attached to a compressed air tank to apply monotonic loading in pressurecontrolled condition. The capacity of the loading system is sufficient to reach the ultimate bearing capacity of the foundation in all tests. During the tests, load and settlement of the footing are measured by an S-shaped load cell having $25 \mathrm{kN}$ capacity with an accuracy of $\pm 0.02 \%$ full scale and a Linear Variable Displacement Transducer (LVDT) having stroke of $100 \mathrm{~mm}$ with an accuracy of $\pm 0.05 \%$ full range, and their measurements are recorded using a data acquisition system.

\section{Materials}

\subsection{Sand}

The soil used in the laboratory tests is a medium-sized silica sand with rough and angular grains and particle sizes greater than $0.6 \mathrm{~mm}$ and smaller than $2.36 \mathrm{~mm}$. Physical properties of the sand are presented in Table 1. It indicates that the relatively uniform soil used in this research can be classified as poorly-graded sand (SP) according to Unified Soil Classification System. All of the experimental tests reported in this paper have been conducted on sand with relative density of $72 \%$ that corresponds to dry unit weight of $16.2 \mathrm{kN} / \mathrm{m}^{3}$.
Table 1. Physical properties of soil.

\begin{tabular}{lc}
\hline \multicolumn{1}{c}{ Parameter } & Value \\
\hline Coefficient of uniformity, $C_{u}$ & 2.18 \\
Coefficient of curvature, $C_{c}$ & 1.38 \\
Effective grain size, $D_{10}(\mathrm{~mm})$ & 0.75 \\
$D_{30}(\mathrm{~mm})$ & 1.29 \\
Medium grain size, $D_{50}(\mathrm{~mm})$ & 1.54 \\
$D_{60}(\mathrm{~mm})$ & 1.63 \\
Specific gravity, $G_{s}$ & 2.67 \\
Dry unit weight, $\gamma\left(\mathrm{kN} / \mathrm{m}^{3}\right)$ & 16.2 \\
Moisture content, $\omega(\%)$ & 0 \\
Maximum void ratio, $e_{\max }$ & 0.878 \\
Minimum void ratio, $e_{\min }$ & 0.575 \\
Relative density, $D_{r}(\%)$ & 72 \\
\hline
\end{tabular}

Table 2. The engineering properties of the reinforcement material used in the tests.

\begin{tabular}{lc}
\hline \multicolumn{1}{c}{ Parameter } & Description \\
\hline Geocell material type & Woven \\
geotextile \\
Polymer & Polyester \\
Thickness, $t(\mathrm{~mm})$ & 0.81 \\
Ultimate tensile strength, $T_{u}(\mathrm{kN} / \mathrm{m})$ & 21.8 \\
Secant modulus at $2 \%$ strain, $J_{2 \%}(\mathrm{kN} / \mathrm{m})$ & 275 \\
Secant modulus at $5 \%$ strain, $J_{5}(\mathrm{kN} / \mathrm{m})$ & 72 \\
Elongation at failure, $\varepsilon_{u}(\%)$ & 25.0 \\
\hline
\end{tabular}

\subsection{Reinforcement}

In this research, a woven geotexile is used to prepare geocell reinforcements with different geometrical properties. It is not selected from commercial geotextiles that are typically applied for reinforcement purposes in practice with the aim of providing the reinforcement with the scaled-down mechanical properties to comply with the modeling scale rules (see Section 4). Therefore, the material is chosen from strips of curtains typically used in office windows. Table 2 provides the engineering properties of the geotextile used in the tests. To fabricate geocell from the geotexile, strips of the geotextile are measured and cut in particular dimensions; they are stitched together in the location of connections using an industrial sewing machine. This procedure provides very uniform and stiff seam at the junction that is much stronger than the parent material under the applied loading.

The photo of the hand-made geocell made from the geotextile is illustrated in Figure 2. In all of the reinforcing samples, geocell pockets are in diamond shape with equilateral diameter designated by " $d$ ". In this paper, height and total width of the geocell are shown by " $h$ " and " $b$ ", respectively. The length of 


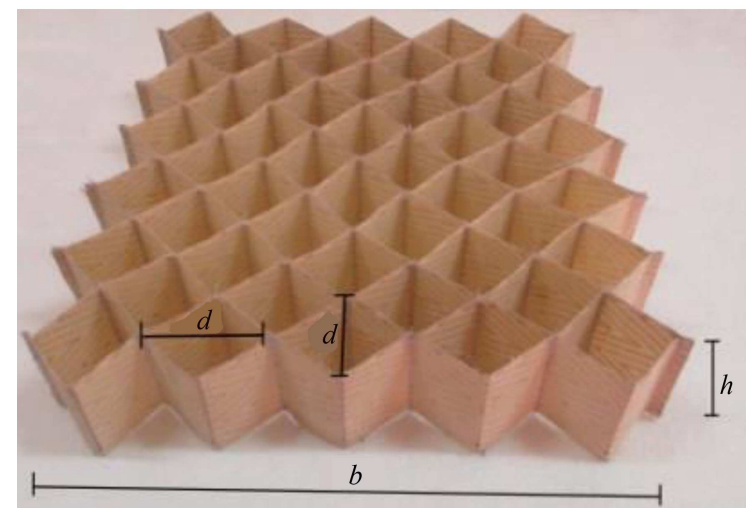

Figure 2. Photographic view of geocell made from geotextile.

the geocell reinforcement perpendicular to the footing width is considered approximately equal to the width of soil tank (length of strip footing model) to provide plane strain conditions.

\section{Experimental test schedule}

The general configuration of the experimental test and the geometrical parameters used in this investigation are presented in Figure 3. All the experimental tests are performed using a $50 \mathrm{~mm}$ width rigid loading plate $(B=50 \mathrm{~mm})$ and the depth of placement of geocell layer is kept constant. The distance between bottom of footing and top of reinforcement is considered $u=5 \mathrm{~mm}$ equivalent to $u / B=0.1$ shown to be the optimum value for geocell placement in the literature (e.g. [19,28]). The geometrical properties of the geocells used in this study with respect to footing width (i.e., $h / B, d / B$, and $b / B)$ are varied in the tests. Table 3 provides the details of experimental test schedule in this research and the objective of each series of tests.

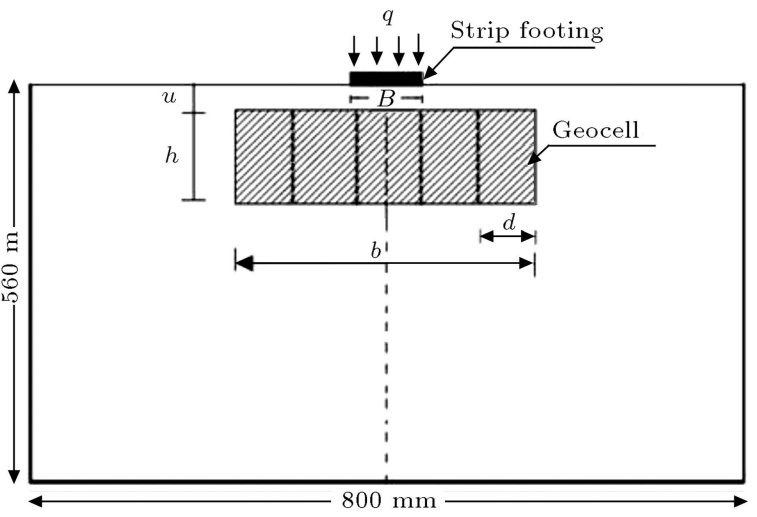

Figure 3. Geometry of the geocell-reinforced bed.

In the experimental tests, the sand bed is prepared homogenously in the test tank by a calibrated raining system. At the particular depth, sand raining is ceased and the geocell reinforcement is located on the surface of sand, while the geocell pockets are stretched to its desired diameter. Then, the infill sand is rained in the pockets of the geocell and raining is continued until the tank is filled. The surface of soil is leveled and footing model is placed on the soil surface in the center of test tank. The static load is then applied at a constant rate of $1 \mathrm{kPa}$ per second until failure is reached.

\section{Results and discussion}

In order to evaluate the performance of geocellreinforced sand foundation, improvements in the bearing capacity and settlement of the footing are expressed by definition of non-dimensional improvement factors with respect to the ultimate loading capacity as well as different levels of footing settlement. The parameters used in the analysis of pressure-settlement behavior of

Table 3. Experimental tests schedule.

\begin{tabular}{|c|c|c|c|c|c|}
\hline $\begin{array}{l}\text { Test } \\
\text { series }\end{array}$ & Reinforcement & $h / B$ & $d / B$ & $b / B$ & Objectives of tests \\
\hline A & Unreinforced & - & - & - & $\begin{array}{c}\text { To quantify the improvements } \\
\text { due to reinforcement }\end{array}$ \\
\hline $\mathrm{B}$ & Geocell & $\begin{array}{c}0.25,0.5,0.75,1 \\
1.25,1.5\end{array}$ & 1 & 5 & $\begin{array}{l}\text { To study the effect of } \\
\text { geocell height }\end{array}$ \\
\hline $\mathrm{C}$ & Geocell & 1 & $0.5,1,1.5,2$ & 5 & $\begin{array}{l}\text { To study the effect of } \\
\text { geocell pocket size }\end{array}$ \\
\hline $\mathrm{D}$ & Geocell & 1 & 1 & $1,2,3,4,5,6,7$ & $\begin{array}{l}\text { To study the effect of } \\
\text { geocell width }\end{array}$ \\
\hline $\mathrm{E}$ & Geocell & $\begin{array}{c}0.25 \text { (4 layers) } \\
0.5 \text { ( } 2 \text { layers }) \\
1 \text { (1 layer })\end{array}$ & 1 & 5 & $\begin{array}{l}\text { To study the effect of } \\
\text { geocell layers number }\end{array}$ \\
\hline
\end{tabular}




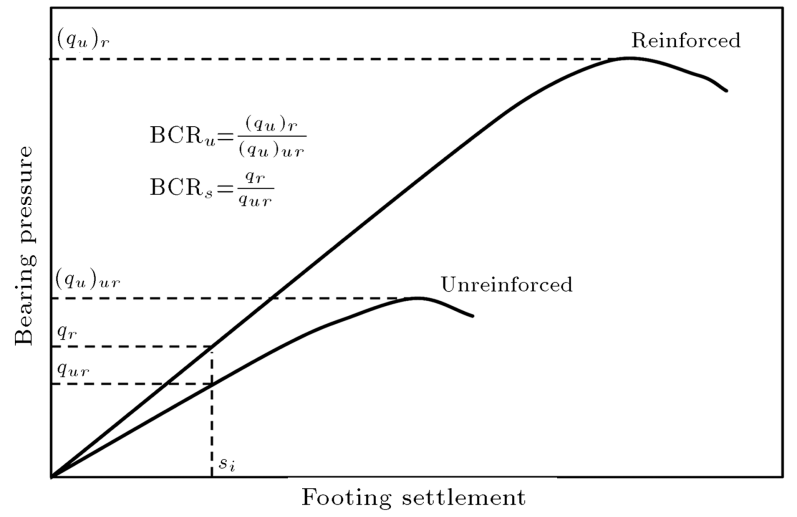

(a)

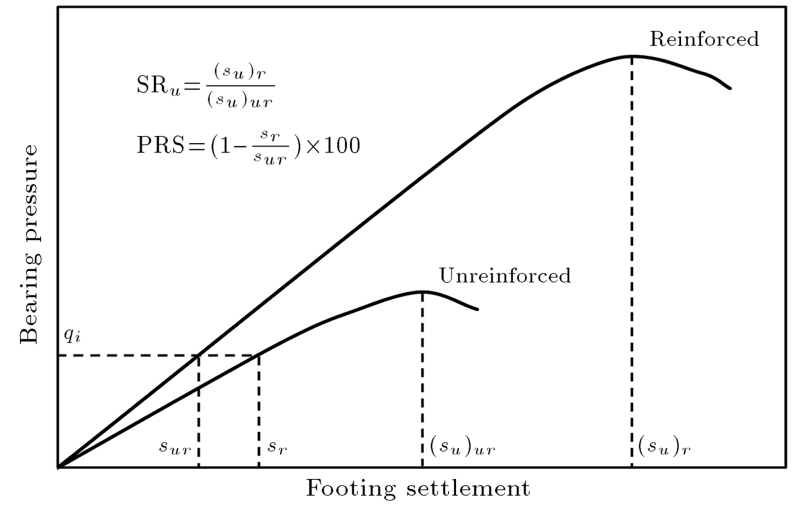

(b)

Figure 4. Definition of parameters to determine improvements of the reinforced soil in terms of (a) bearing capacity and (b) settlement.

the footing are defined in Figure 4 and the improvement factors are described as follows:

- $\mathrm{BCR}_{u}$ : The ratio of ultimate bearing capacity of the reinforced to unreinforced soil;

- $\mathrm{BCR}_{s}$ : The ratio of bearing pressure of the reinforced to unreinforced soil at a given settlement level;

- $\mathrm{SR}_{u}$ : The ratio of ultimate settlement of the reinforced to unreinforced soil;

- PRS: Percentage reduction in settlement at a given pressure level.

In this section, the results of the experimental tests are presented and the effect of different geometrical parameters on the performance of the reinforced soil is discussed through comparison of the above mentioned improvement factors.

\subsection{Effect of geocell height}

Test series A is carried out on unreinforced sand bed, and tests series B are conducted to study the effect of geocell height on the performance of reinforced sand. Figure 5 shows the pressure-settlement behavior of footings on unreinforced sand and reinforced

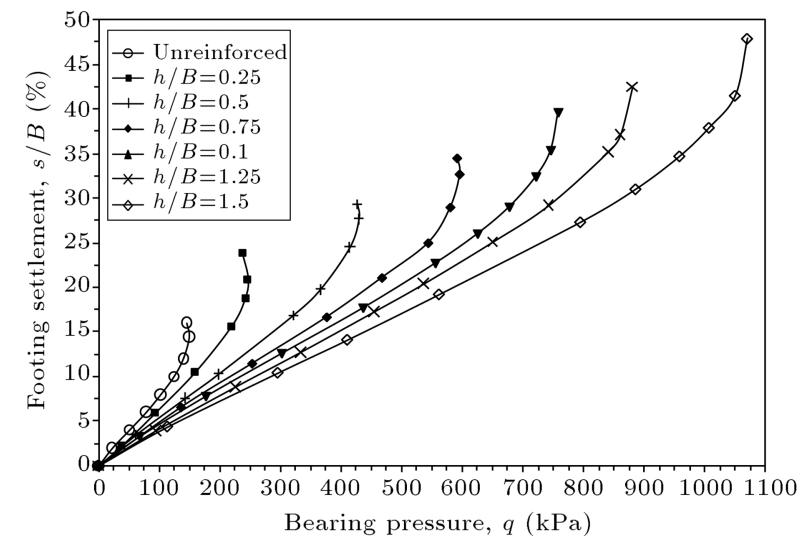

Figure 5. Variation of bearing pressure with footing settlement for different heights of geocell mattress $(d / B=1, b / B=5)$.

sand with different geocell heights. Generally, provision of geocell-reinforcement significantly increases the bearing capacity of the footing compared to the unreinforced soil. The geocell foundation mattress has turned the pressure-settlement response of the footing into a highly linear behavior up to high levels of settlement. Failure zones on the surface of reinforced soil have extended to a considerably larger distance beyond the edge of strip footing compared to the unreinforced sand. The geocell mattress acts as a secondary foundation that redistributes footing stresses over a wider area in the bottom of geocell cushion with a dispersion angle [6,29]. Therefore, it transmits the footing load over a wider area giving rise to a better performance. It is also evident from Figure 5 that the bearing capacity is increased significantly by increase in the height of the geocell. In addition, the stiffness of the reinforced soil is also increased which leads to less footing settlement at a specific pressure level. By increasing the height of the geocell mattress, the overall frictional resistance on the geocell walls increases because of the increase in the surface area which resists the downward movement of the soil. As a result, the entire geocell mattress behaves as a composite body, thereby giving rise to a better performance improvement. Besides, with increase in the height of the geocell layer, the moment of inertia and the bending rigidity of the geocell mattress increase, which redistributes the footing pressure over a wider area, and therefore increases the performance of the footing.

Figure 6(a) shows the variation of ultimate bearing capacity ratio with geocell height. It can be seen that by increasing geocell height from $h / B=0.25$ to $h / B=1.5, \mathrm{BCR}_{u}$ increases from 1.6 to 7.1 . It is also evident that by using a geocell with greater height, the soil under the footing is able to remain stable under larger settlements without failure. According to Figure 6(b), the ultimate settlement ratio, $\mathrm{SR}_{u}$, increases from 1.4 to 3.3 when the ratio of geocell 


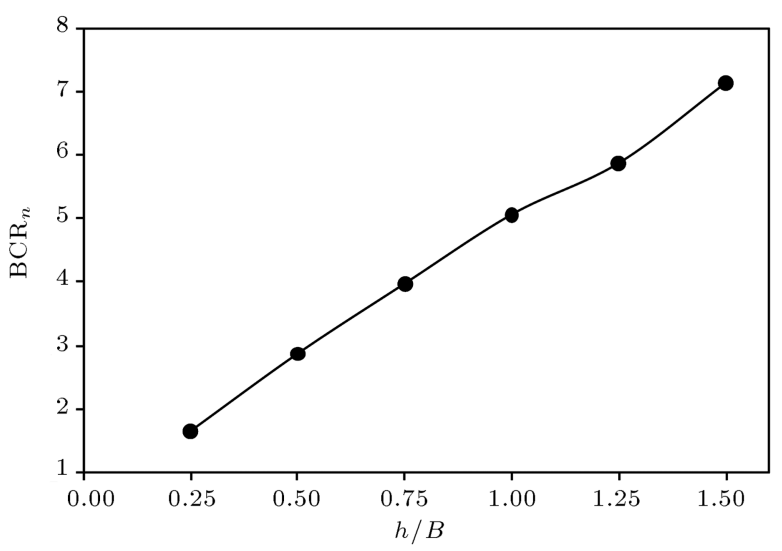

(a)

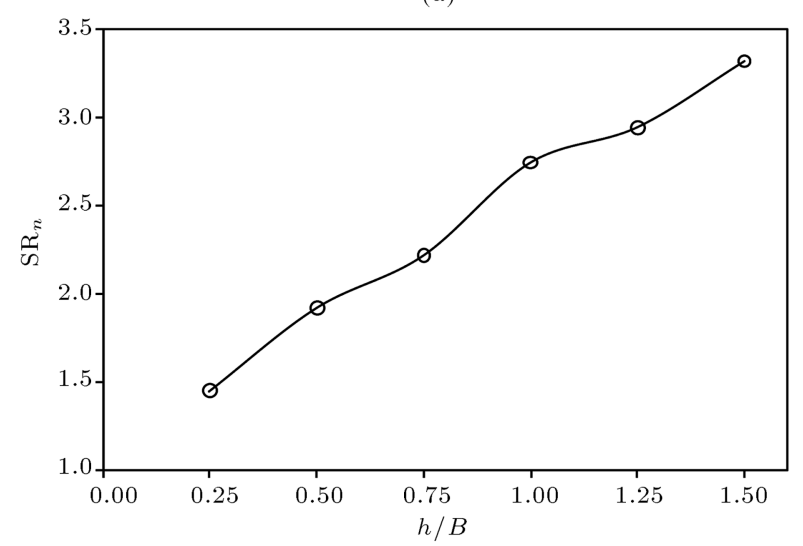

(b)

Figure 6. Influence of geocell height on (a) ultimate bearing capacity ratio and (b) ultimate settlement ratio.

height to footing width $(h / B)$ increases from 0.25 to 1.5. Figure 7 shows the influence of geocell height on the improvement in bearing capacity and settlement reduction of footing at different levels of settlement. Since the improvement is assessed with respect to the unreinforced sand and there is no data after the ultimate settlement ratio for the unreinforced sand, the maximum settlement investigated in Figure 7 is considered $14 \%$ of footing width beyond which the settlements are usually not allowed in engineering practice.

The confinement, provided due to high stiffness of geocell walls made from woven geotextile, restrains the lateral movements of soil particles inside the geocell. However, improvement in increasing the bearing pressure and reducing the footing settlement is increasing with higher settlement levels as more confinement will be induced in the soil (Figure 7(a)). At low levels of settlement, the pressure induced by footing loads tends to make the infill sand rearrange in a denser packing, and the frictional resistance of the soil-reinforcement interface restrains the movements of soil particles due to the rough texture of the geocell walls. As shown in Figure 7(a), at settlement level of $s / B=2 \%$, the bearing capacity ratio increases from

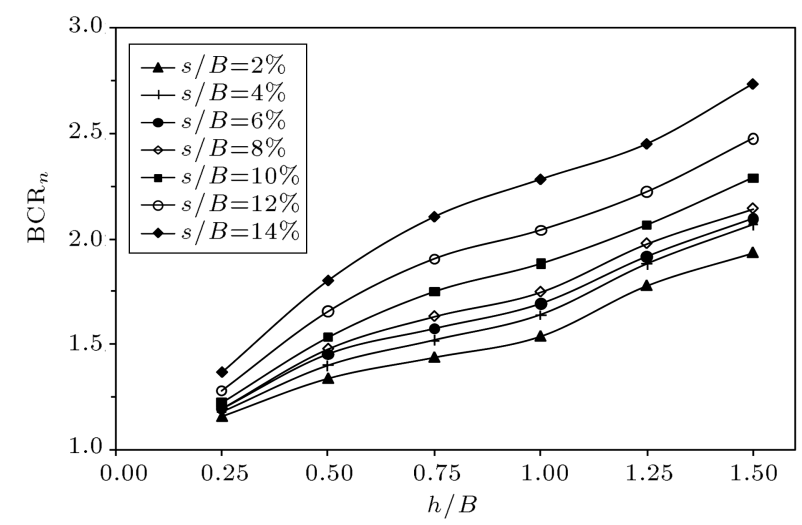

(a)

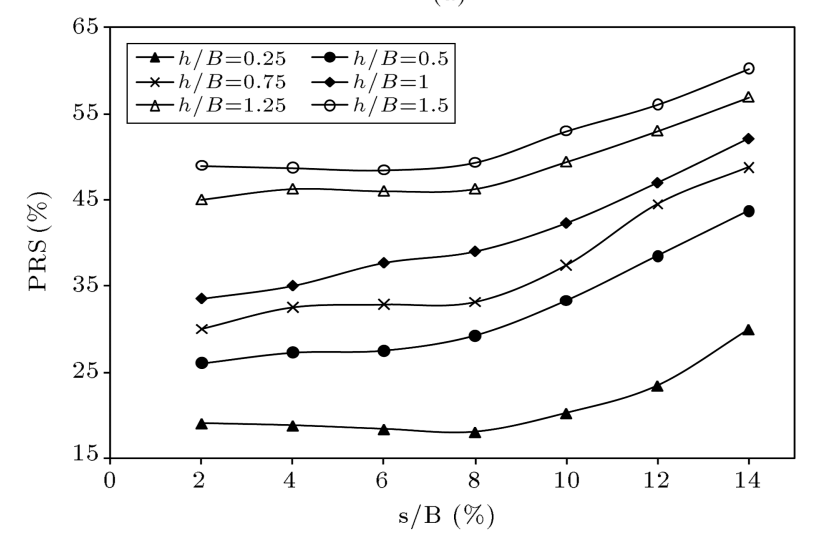

(b)

Figure 7. Influence of geocell height on (a) bearing pressure improvement and (b) settlement reduction at different footing settlement levels.

1.2 to 1.9 by increasing geocell height from $h / B=0.25$ to $h / B=1.5$ demonstrating the influence of geocell height on bearing capacity even at low levels of footing settlements.

At higher ranges of settlement, the geocell performance would be enhanced as catenary shape deformation occurs and the membrane effect of the geocell reinforcements develops a tensile force in the reinforcement. The vertical component of this force resists the downward movement of the footing and increases the bearing pressure. By increasing the level of footing pressure and settlement, the sand in the geocell pockets, next to footing, starts to move upward as it overcomes the frictional resistance. Moreover, the excessive bending of the reinforced sand cushion causes high levels of horizontal tensile strains in the bottom axis of geocell walls located beneath the center of footing width. At this stage, for geocells with $h / B>0.5$, the points below the middle axis of geocell walls under the footing center undergo large strains up to the ultimate strain and rupture happens in the geocell. Consequently, a sudden shear failure takes place leading to a large heave in the soil surface beside the footing width and the infill soil of the geocell moves out of the pockets. It should be noted that the rupture 
zone in geocell wall increases with increase in geocell height. For geocells of lower heights $(h / B=0.25,0.5)$, the failure mechanism is slightly different, and the soil will fail prior to reaching the strain in the geocell wall to its ultimate failure strain. Therefore, no distinctive damage is observed in the geocell wall material and only bending deformation of geocell is recognizable.

It should also be noted that although in the range of geocell heights investigated in the current experimental tests $(h / B=0.25-1.5)$ the bearing capacity improvement has shown direct increase in proportion to the height of geocell layer, there should be a certain $h / B$ ratio beyond which the increased bending rigidity of the geocell layer remains immobilized; therefore, the pressure-settlement responses do not show a significant change. This value is reported around $h / B=2$ beyond which marginal improvement is anticipated $[16,19]$ that is believed to be due to the fact that zone of soil influenced by the footing loading extends to about two times the footing width [30].

\subsection{Effect of geocell pocket size}

Test series $\mathrm{C}$ is carried out to investigate the effect of geocell pocket diameter on the behavior of geocellreinforced sand. Figure 8 presents the variation of bearing pressure with footing settlement for different geocell pocket sizes. It can be seen that increasing the geocell pocket diameter decreases the bearing capacity and stiffness of reinforced sand. As the diameter of geocell pocket increases, the number of cells under the loading area decreases leading to less confinement effect. Figure 9 shows the variation of ultimate bearing capacity ratio and ultimate settlement ratio with geocell pocket size. As shown in Figure 9, by increasing geocell pocket diameter from $d / B=0.5$ to $d / B=2$, $\mathrm{BCR}_{u}$ decreases from 6.7 to 2.6 and $\mathrm{SR}_{u}$ decreases from 3.2 to 2 . It can also be observed that the variations of the ultimate bearing capacity ratio and the ultimate settlement ratio with geocell pocket diameter are not

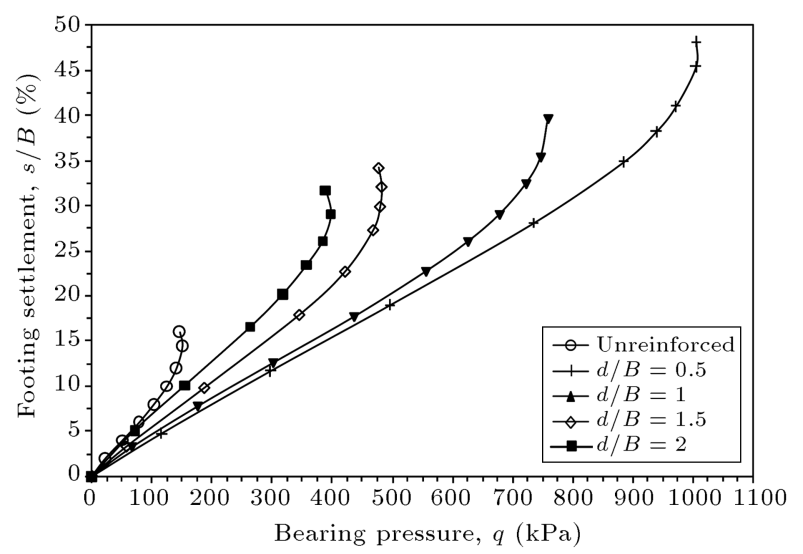

Figure 8. Variation of bearing pressure with footing settlement for different pocket diameters of geocell mattress $(h / B=1, b / B=5)$.

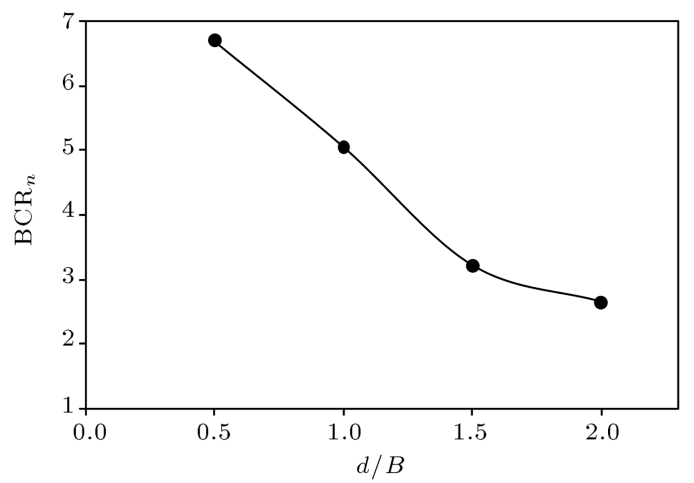

(a)

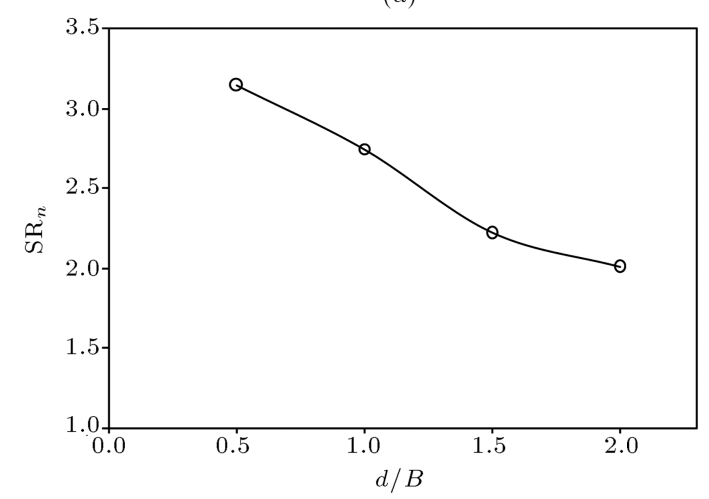

(b)

Figure 9. Influence of geocell pocket diameter on (a) ultimate bearing capacity ratio and (b) ultimate settlement ratio.

linear since the downward trend of $\mathrm{BCR}_{u}$ and $\mathrm{SR}_{u}$, by increasing pocket diameter, decreases for geocell diameters greater than $d / B=1.5$.

Figure 10 shows the influence of geocell pocket size on bearing capacity and settlement reduction at different settlement levels. As shown in Figure 10(a), the improvement in bearing capacity, due to the decrease in geocell pocket diameter, increases with footing settlement. When footing settlement rises from $s / B=2 \%$ to $s / B=14 \%$, bearing capacity ratio increases from 1.8 to 2.4 for the geocell with $d / B=0.5$ and increases from 1.1 to 1.5 for geocell with $d / B=2$. The better performance of geocell with $d / B=0.5$ at low settlement levels can be ascribed to the greater number of cell joints under loading plate which result in greater confinement. Figure 10(b) indicates that at low ranges of footing settlement levels $(s / B<6 \%)$, percentage reduction in settlement is approximately constant. However, it increases substantially with decrease in geocell pocket size. For geocell pocket size of $d / B=2$, the influence of geocell reinforcement on reduction of footing settlement at low levels is marginal (about 5\%), but for geocell pocket size of $d / B=0.5$, geocell reinforcement leads to $45 \%$ reduction in footing settlement. It implies that for better improvement of geocell performance under the footing, the pocket size of geocell should not be large with respect to 


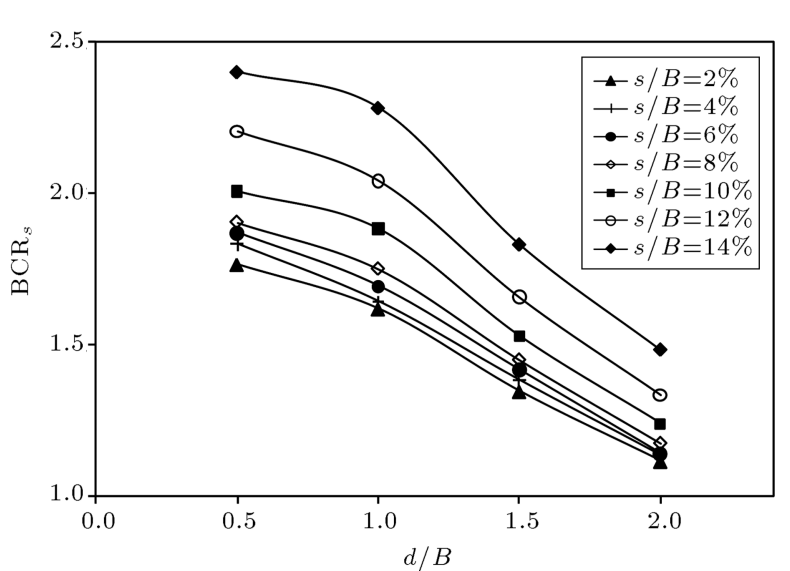

(a)

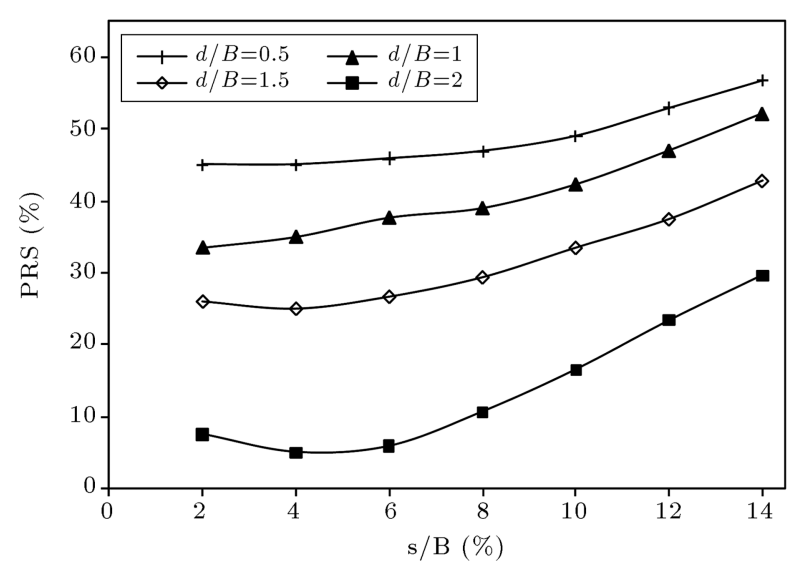

(b)

Figure 10. Influence of geocell pocket diameter on (a) bearing pressure improvement and (b) settlement reduction at different footing settlement levels.

the footing width. For example, in these tests, when $d / B$ goes up to higher than 1.5 , its performance improvement reduces significantly, especially at low ranges of settlement. The reason is that the soil directly under the footing cannot be confined suitably in the large pockets. At higher ranges of settlements, however, the significance of geocell reinforcement in decreasing footing settlements increases. For example, at $s / B=14 \%$ even in the case of $d / B=2$, there is $30 \%$ decrease in settlements, and in the case of $d / B=0.5$, the percentage reduction in settlement is $57 \%$ (Figure 10(b)).

\subsection{Effect of geocell width}

Tests series D are conducted to investigate the influence of geocell width on the pressure-settlement response of the footing. The experimental tests are carried out on geocells with $h / B=d / B=1$. Figure 11 shows the variation of bearing pressure with footing settlement for geocell reinforcements with different widths. When geocell width increases, footing loads distribute over a larger area due to rigidity of the geocell layer. Therefore, lower pressures are transferred to the underneath

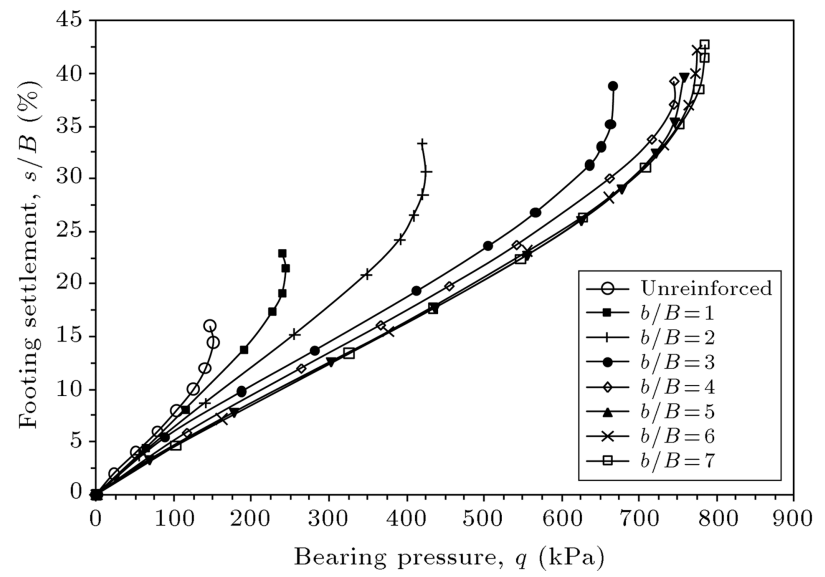

Figure 11. Variation of bearing pressure with footing settlement for different widths of geocell mattress $(h / B=1, d / B=1)$.

soil. However, when the geocell width reaches an optimum value, the effect of improvement becomes negligible after which it does not have any considerable effect on the bearing capacity and settlement of the footing. According to Figure 11, this optimum value can be considered $b / B=5$ corresponding to extension of geocell width to two times of footing width in each side of the footing. This extension provides anchorage from both sides of the loaded area due to the frictional and passive resistance developed at the soil-geocell interfaces.

Figure 12 shows the effect of geocell width on ultimate bearing capacity ratio and ultimate settlement ratio of footing. It can be seen that increasing the geocell width ratio from $b / B=1$ to $b / B=3$ significantly increases the ultimate bearing capacity ratio (from 1.6 to 4.4 ), which can be attributed to the fact that extending the geocell width to the both sides of the footing width edge leads to interception of failure planes and geocell mattress. However, further increase in geocell width shows improvement in the ultimate bearing capacity, with a slower trend and increasing $b / B$ to more than 5 , shows a marginal improvement in ultimate bearing capacity which is practically negligible. Similarly, increasing geocell width leads to increase in the ultimate settlement ratio, but the effect becomes negligible for geocells wider than 5B. Furthermore, it is interesting to note that even for the case of a short geocell mattress with the width equal to footing width, despite the incapability of geocell mattress to control the failure planes, the ultimate bearing capacity and ultimate settlement have increased 1.6 and 1.5 times, respectively. It is due to the performance of geocell mattress as a rigid cushion to transfer the footing load to the base of geocell which behaves like a footing with embedded depth.

Figure 13(a) shows the variation of bearing capacity ratio with geocell width at different levels of 


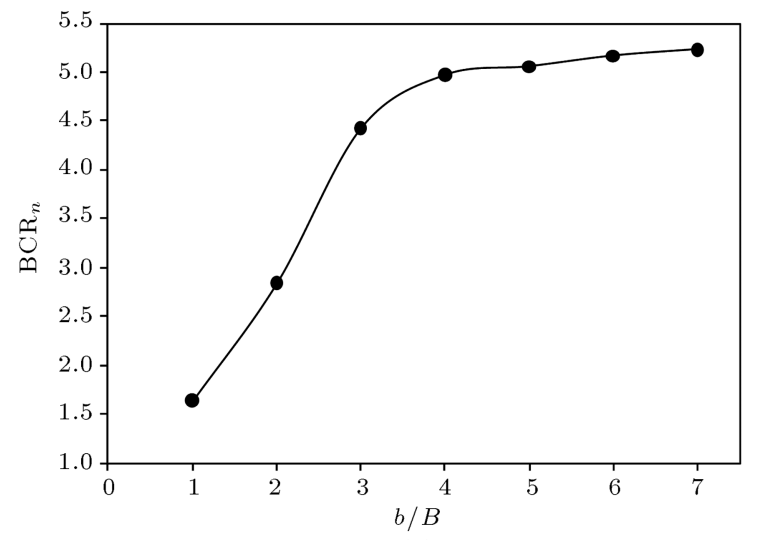

(a)

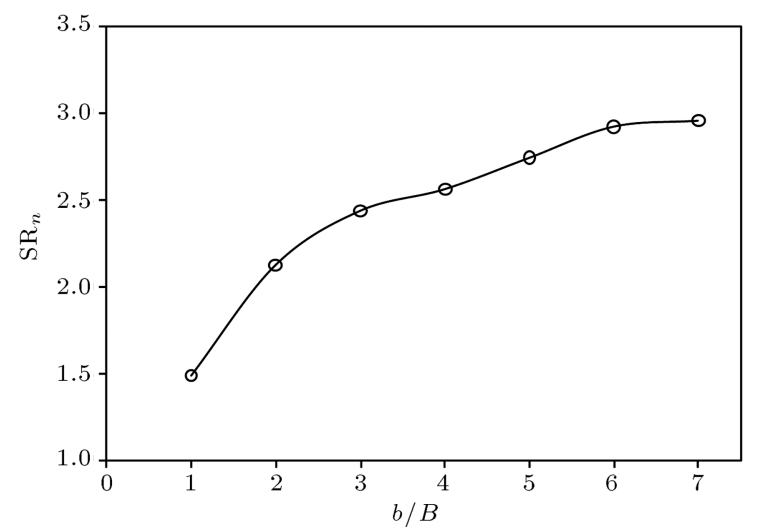

(b)

Figure 12. Influence of geocell width on (a) ultimate bearing capacity ratio and (b) ultimate settlement ratio.

footing settlement. It can be seen that increasing geocell width up to $b / B=5$ increases the bearing pressure substantially, but the effect of further increase in geocell width is only marginal. At settlement ratio of $\mathrm{s} / \mathrm{B}=14 \%$, bearing capacity ratio increases from 1.3 to 2.3 by increasing geocell width from $b / B=1$ to $b / B=$ 5 , but it remains constant for geocells with greater widths. It is also obvious that the efficiency of geocell reinforcement in increasing bearing capacity goes up by increasing footing settlement. Figure 13(b) shows the variation of percentage reduction in settlement with footing settlement for geocells with different widths. It is evident that at settlement ranges of $s / B \leq 6 \%$, the rate of increase in PRS with settlement level is not noticeable. However, for higher settlement ranges $(s / B>6 \%)$, soil reinforcement increases the value of PRS significantly which implies that the internal confinement, provided by geocell inclusion, increases with increase in the imposed settlement level on the reinforced system.

\subsection{Effect of geocell layers number}

In test series $\mathrm{E}$, geocell reinforcement with $h / B=1$ is replaced with distinctive arrangements of geocell layers with equivalent total height. In one case, two layers of geocell with $h / B=0.5$ are used; in another state,



(a)

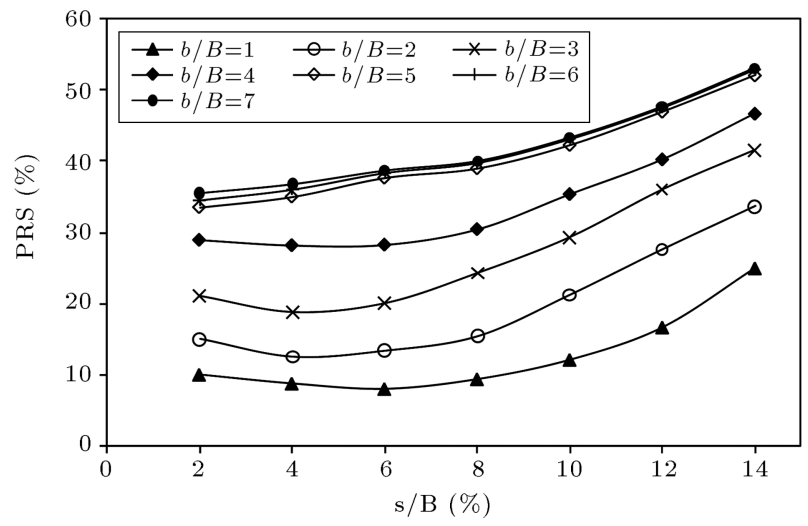

(b)

Figure 13. Influence of geocell pocket width on (a) bearing pressure improvement and (b) settlement reduction at different footing settlement levels.

four layers of geocell with $h / B=0.25$ are applied with no distance between the layers of geocell so that the ultimately-produced mattresses are of the similar height. The objective is to investigate the effect of substituting a geocell with several number of smaller height geocells on the pressure-settlement response. The results might be interesting in engineering practice regarding the selection of reinforcement specifications.

Figure 14 shows the variation of bearing pressure with footing settlement for different number of geocell layers. It can be seen that although all tests have similar reinforcements, the pressure-settlement responses are different. As shown in Figure 14, by increasing the number of geocell layers, both the bearing capacity and stiffness of the reinforced sand foundation decrease. In the state of one layer of geocell with $h / B=1$, as previously described, the geocell layer deforms like a slab under distributed loading in the center. Therefore, at large footing settlements, high horizontal tensile strain develops in the bottom axis of the cell walls directly under the footing center. At failure, the strain at almost lower half of the geocell wall reaches the textile ultimate strain and eventually rupture takes place in these zones of textile giving rise to sudden failure of reinforced soil under the footing. When 


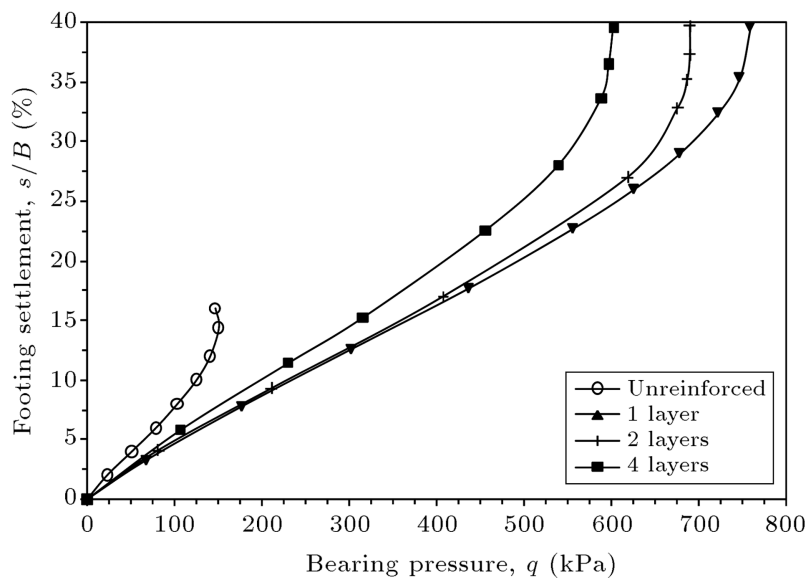

Figure 14. Variation of bearing pressure with footing settlement for different geocell layer numbers $(h / B=1$, $d / B=1, b / B=5)$.

two layers of geocell with $h / B=0.5$ are used, the tensile strain in the lower geocell wall leads to complete breakage and separation into two parts. In this case, in contrast to one layer geocell, reinforcement tensile stresses cannot be transferred to higher levels due to disconnection from the two geocells. Therefore, ultimate bearing capacity is decreased slightly. For the case of four layers of geocell with $h / B=0.25$, no special failure has occurred in the geocell wall (even in the bottom geocell) which shows less mobilization of geocell strains. Consequently, ultimate bearing capacity decreases considerably.

According to Figure 15(a), the ultimate bearing capacity ratio of geocell-reinforced soil is 5.1, 4.6, and 4 for the cases of one, two, and four layers, respectively. It implies that substituting a geocell with two geocells of half height and four geocells of quarter height causes $10 \%$ and $22 \%$ reductions in the ultimate bearing capacity of reinforced soil, respectively, which is attributed to alteration in failure mechanism taking place for different cases. However, Figure 15(b) shows that the ultimate settlement ratio is approximately similar in all conditions.

Figure 16 shows the influence of geocell layer number in bearing pressure improvement and settlement reduction at footing settlements levels up to $14 \%$ of footing width. As can be seen in Figure 16(a), bearing capacity ratio has decreased by increasing the number of geocell layers. However, the decreasing trend is more noticeable when there are four layers of geocells compared to two layers of geocell, especially at higher settlement ranges. By increasing the footing settlement, this aggravating effect would be more noticeable. For example, at settlement ratio of $s / B=14 \%$, bearing capacity ratio is $2.3,2.2$, and 1.9 corresponding to one, two, and four geocell layers indicating that replacement of a geocell by two layers of geocells with half height and four layers of geocells with quarter height causes

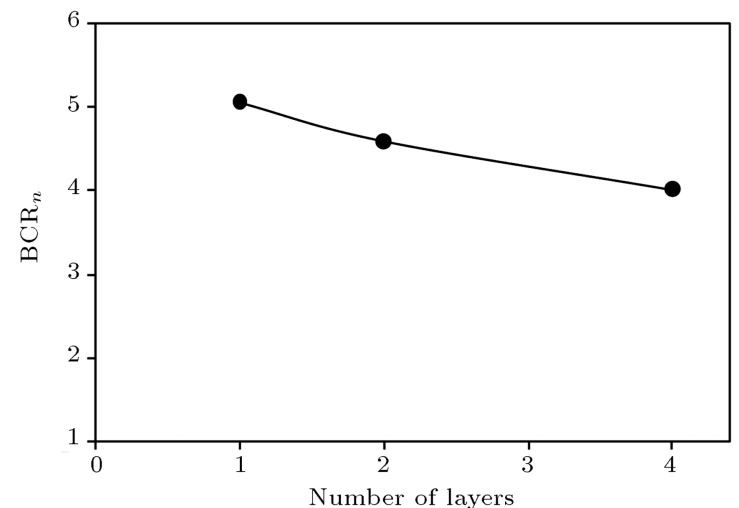

(a)

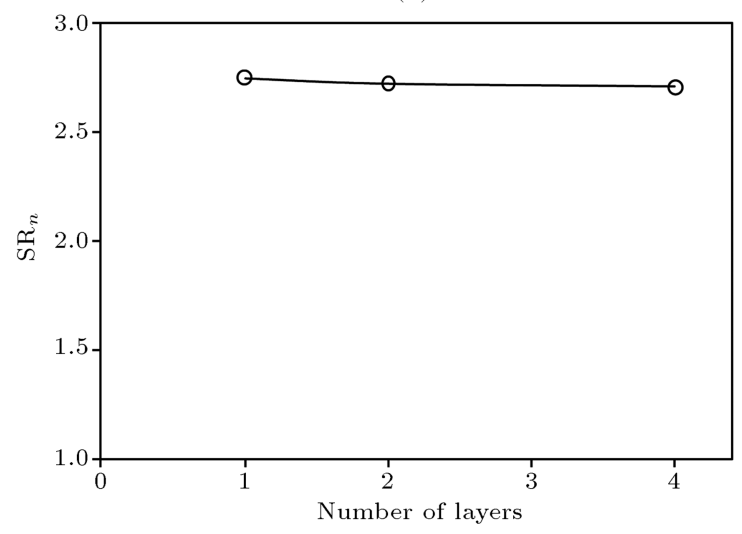

(b)

Figure 15. Influence of number of geocell layers on (a) ultimate bearing capacity ratio and (b) ultimate settlement ratio.

$3.5 \%$ and $15 \%$ reductions in bearing capacity at this settlement level. Also, Figure 16(b) indicates that four layers of geocell reinforcement layers have decreased the efficiency of geocell in reduction of footing settlement. It can be due to relative sliding of geocell layers that prohibits integrated performance of geocell mattress.

\subsection{Comparison of the effect of different geometrical properties}

To assess the importance of different geocell geometrical properties on the performance improvement of geocell-reinforced sand foundations, a cost-benefit analysis is made through comparison of the amount of material used to produce geocells with different geometries in terms of surface area (i.e., the product of width, height and number of geotextile strips used to make geocells) and the bearing capacity ratio. Figure 17 shows the variation of bearing capacity with geocell surface area at the ultimate settlement level, settlement level of $s / B=14 \%$ and $s / B=6 \%$, respectively. As seen in Figure $17(\mathrm{a})$, as long as the failure of reinforced soil foundation is concerned, the most influential geometrical parameter is the geocell total width on condition that it remains less than $b / B=5$. And, for the geocells with $b / B>5$, the effect of width turns out to be fruitless, and geocell 


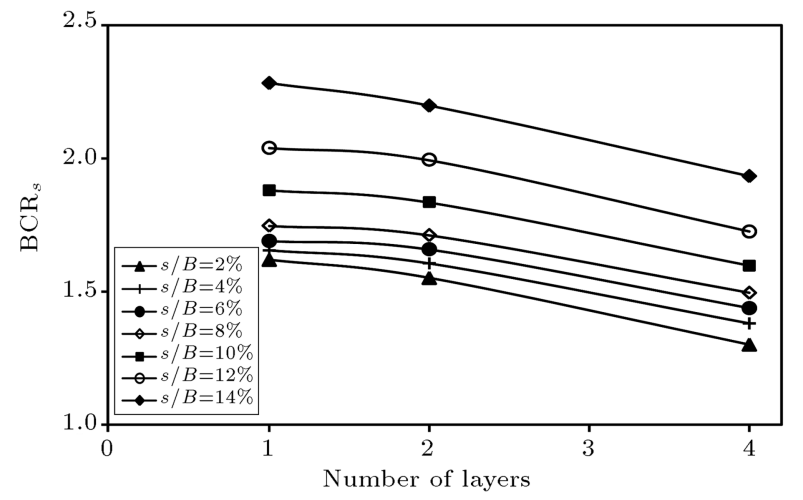

(a)

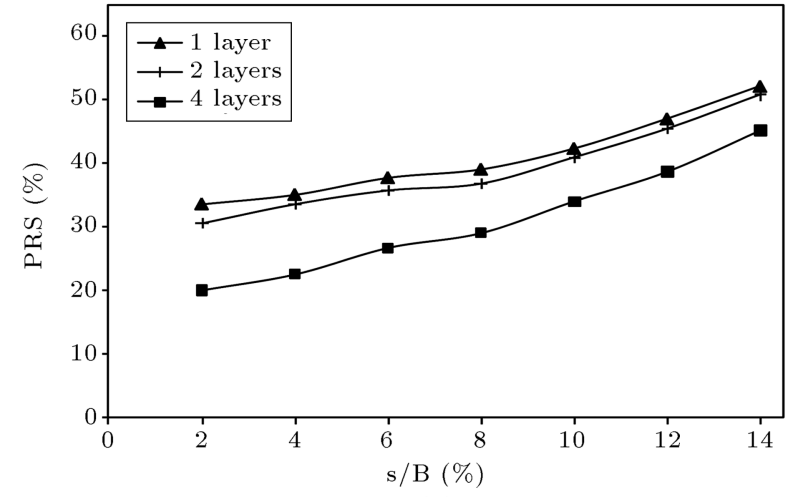

(b)

Figure 16. Influence of number of geocell layers on (a) bearing pressure improvement and (b) settlement reduction at different footing settlement levels.

height would be the most significant parameter in increasing bearing capacity. However, the ultimate failure level is not usually of design interest in practice due to the corresponding high levels of settlement at failure.

For settlement level of $s / B=14 \%$, as shown in Figure 17(b), both the width and height of geocell have almost similar influences if geocell width is not greater than $b / B=5$. And, for wider reinforcements, geocell height effect is the most noticeable. For lower footing settlement levels (e.g., $s / B=6 \%$ ), which are usually more important in practice, the most distinguished parameter is the height of geocell as presented in Figure 17(c). Therefore, it can be concluded that the effectiveness of geocell geometrical properties depends highly on the level of settlement. In the range of geometrical conditions studied in this paper, geocell height is found to be the most influential factor in the performance improvement of reinforced soil. However, for geocells with $b / B<5$, the effect of geocell width at high levels of settlement is more noticeable.

\section{Limitations and applicability}

In this research, the experimental tests have been conducted on a reduced-scale physical model of footing

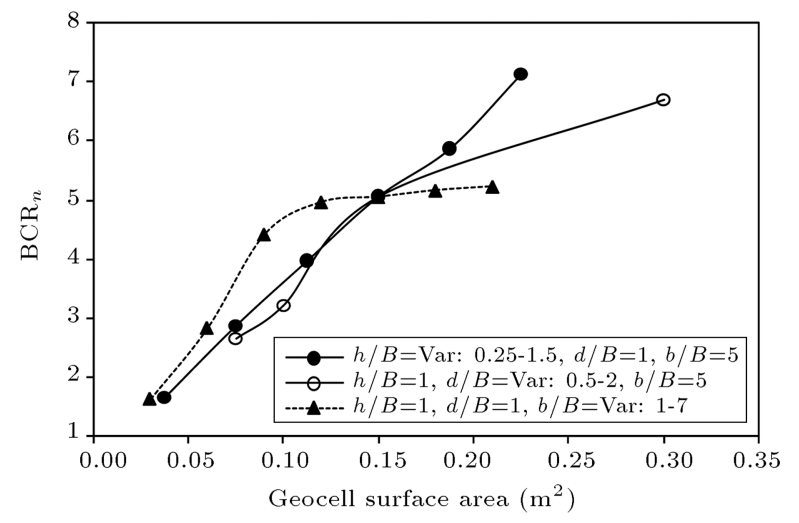

(a)



(b)

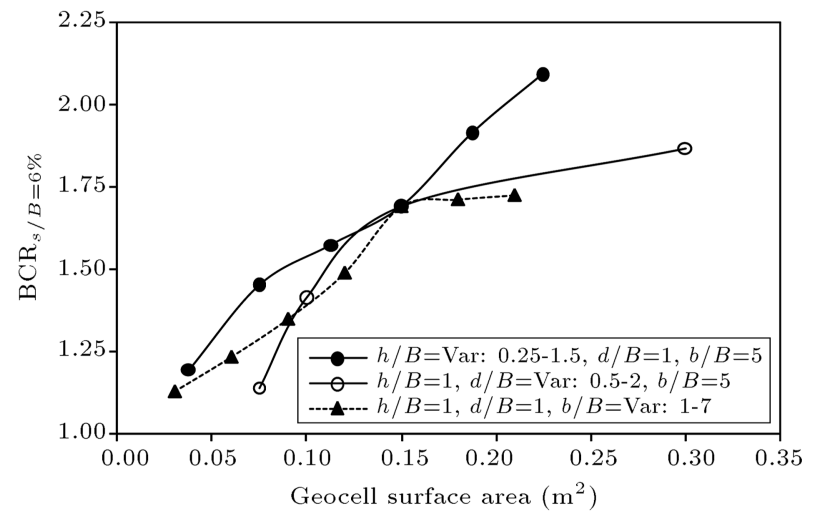

(c)

Figure 17. Variation of bearing capacity ratio with geocell surface area at (a) ultimate settlement, (b) $s / B=14 \%$, and (c) $s / B=6 \%$.

on reinforced sand. Therefore, for the findings of the present study to be applicable in practice, scale effects should be considered. Although the general mechanisms and qualitative behavior of laboratoryscaled and full-scale conditions are similar, quantitative evaluation of the pressure-settlement response of geocell-reinforced sand in the field from the results of this study is valid only if scale factors, as mentioned in Table 4, are taken into account [31,32]. For example, considering a scale factor of $N=4$ (based on typical dimensional properties of commercially-produced geocells), a geocell with secant modulus of $4400 \mathrm{kN} / \mathrm{m}$ 
Table 4. Scale factors for geocell-reinforced soil physical modeling.

\begin{tabular}{lc}
\hline \multicolumn{1}{c}{ Parameter } & Scale factor \\
\hline Dimensions: $B, h, d, b, t, u$ & $N$ \\
Soil density, $\gamma$ & 1 \\
Soil modulus, $E$ & $N$ \\
Geosynthetics tensile strength, $T_{u}$ & $N^{2}$ \\
Geosynthetics modulus, $J$ & $N^{2}$ \\
Bearing pressure, $q$ & $N$ \\
Relative settlement, $s / B$ & 1 \\
\hline
\end{tabular}

(i.e., $275 \mathrm{kN} / \mathrm{m} \times 16$ ) and ultimate strength of about $350 \mathrm{kN} / \mathrm{m}$ (i.e., $21.8 \mathrm{kN} / \mathrm{m} \times 16$ ) is required for the improvement factors obtained from the present study to be applicable in real project. It should be noted that if the strength and stiffness of geoecll wall material or geocell joint in the field is lower than abovementioned mechanical properties (which would most likely be so, because the scaled mechanical properties are almost an upper bound value for the commerciallyavailable geosynthetics), the results presented in this study would overestimate the beneficial effect of geocell inclusion, and improvement factors would be higher than those in practice.

The results of this study can be used to guide geotechnical engineers in selecting an appropriate geometrical parameter for design of footings on geocellreinforced sand. However, the current investigation has been restricted to the experimental tests on only one type of geocell material, one type of sand, and one size of footing width. Thus, specific applications using the quantitative results should only be made after considering this limitation. The results could also be helpful in designing large-scale model tests and simulating through numerical models.

\section{Conclusions}

In this paper, the results of laboratory model tests, which investigated the improvement effect of geocellreinforced sand foundations, are presented. Geocells with different geometrical characteristics are provided using a woven geotextile material and the influence of geocell height, pocket size, width, and number of layers on the pressure-settlement response of the strip footing is studied. The improvement in the performance of geocell-reinforced sand is assessed in terms of increasing the bearing pressure and percentage reduction in settlement for practically acceptable levels of settlements and for the ultimate failure level. By comparing the behavior of geocell-reinforced sand under footing load, the following conclusions can be drawn:

- Geocell reinforcement improves the bearing capacity of foundation systems substantially. The geometri- cal properties of geocell in reinforced sand bases have a significant influence on the pressure-settlement response of footings. Height, pocket size, width, and number of geocell layers determine the effectiveness of confinement and stress dispersion mechanisms and have a considerable impact on failure mechanism of the geocell-reinforced sand;

- Height of geocell layer is the most influential parameter of geocell-reinforced sand. Increasing geocell height from $h / B=0.25$ to $h / B=1.5$, in this study, increases the ultimate bearing capacity ratio from 1.6 to 7.1 . For the woven geotextile material used to make geocell, failure in the geocell wall material occurs only for geocells with $h / B>0.5$ in which the ruptured zone in the center of footing commences from the bottom of geocell wall and spreads to upper levels by footing penetration and is greater for geocells with higher $h / B$;

- Increase in geocell pocket size reduces the improvement in performance of geocell-reinforced sand. Increasing the geocell pocket diameter to more than $d / B=1$ decreases the number of cells directly under the footing, and hence less confinement is developed. Therefore, efficiency of geocell in increasing the bearing pressure and reduction of settlement decreases substantially, especially at low levels of footing settlement;

- Conspicuous improvement in bearing capacity and settlement of geocell-reinforced sand is obtained by increasing the width of geocell layer up to $5 \mathrm{~B}$, beyond which further improvement is marginal;

- Substituting a geocell reinforcement with multilayer geocells of the equivalent accumulated height results in reduction of bearing capacity and stiffness of reinforced sand bed. Therefore, it is preferred to apply the highest geocell available in practice than to use several geocells with lower heights.

\section{Acknowledgments}

The authors would like to thank Professor Richard Bathurst for his valuable comments and suggestions during the first author's visiting period in geoengineering center at Queen's-RMC.

\section{References}

1. Zhang, L., Zhao, M., Shi, C. and Zhao, H. "Bearing capacity of geocell reinforcement in embankment engineering", Geotextiles and Geomembranes, 28(3), pp. 475-482 (2010).

2. Bathurst, R.J. and Karpurapu, R. "Large-scale triaxial compression testing of geocell-reinforced granular soils", Geotechnical Testing Journal, ASTM, 16(3), pp. 296-303 (1993). 
3. Rajagopal, K., Krishnaswamy, N.R. and Madhavi Latha, G. "Behavior of sand confined with single and multiple geocells", Geotextiles and Geomembranes, 17(3), pp. 171-184 (1999).

4. Chen, R.H., Huang, Y.W. and Huang, F.C. "Confinement effect of geocells on sand samples under triaxial compression", Geotextiles and Geomembranes, 37, pp. 35-44 (2013).

5. Indraratna, B., Biabani, M. and Nimbalkar, S. "Behavior of geocell-reinforced subballast subjected to cyclic loading in plane-strain condition", Journal of Geotechnical and Geoenvironmental Engineering, ASCE, 141(1), pp. 1-16 http://dx.doi.org/10.1061/(ASCE) GT.1943-5606.0001199 (2015).

6. Madhavi Latha, G., Dash, S.K. and Rajagopal, K. "Numerical simulation of the behavior of geocell reinforced sand in foundations", International Journal of Geomechanics, ASCE, 9(4), pp. 143-152 (2009).

7. Dash, S.K., Rajagopal, K. and Krishnaswamy, N.R. "Strip footing on geocell reinforced sand beds with additional planar reinforcement", Geotextiles and Geomembranes, 19 (8), pp. 529-538 (2001).

8. Dash, S.K., Sireesh, S. and Sitharam, T.G. "Model studies on circular footing supported on geocell reinforced sand underlain by soft clay", Geotextiles and Geomembranes, 21(4), pp. 197-219 (2003).

9. Sitharam, T.G. and Sireesh, S. "Behavior of embedded footings supported on geogrid cell reinforced foundation beds", Geotechnical Testing Journal, ASTM, 28(5), pp. 452-463 (2005).

10. Sitharam, T.G., Sireesh, S. and Dash, S.K. "Model studies of a circular footing supported on geocellreinforced clay", Canadian Geotechnical Journal, 42(2), pp. 693-703 (2005).

11. Madhavi Latha, G., Rajagopal, K. and Krishnaswamy, N.R. "Experimental and theoretical investigations on geocell-supported embankments", International Journal of Geomchanics, ASCE, 6(1), pp. 30-35 (2006).

12. Leshchinsky, B. and Ling, H.I. "Effects of geocell confinement on strength and deformation behavior of gravel", Journal of Geotechnical and Geoenvironmental Engineering, ASCE, $\mathbf{1 3 9}$ (2), pp. 340-352 (2013).

13. Tanyu, B.F., Aydilek, A.H., Lau, A.W., Edil, T.B. and Benson, C.H. "Laboratory evaluation of geocell-reinforced gravel subbase over poor subgrades", Geosynthetics International, 20(2), pp. 47-61 (2013).

14. Moghaddas Tafreshi, S.N., Khalaj, O. and Dawson, A.R. "Repeated loading of soil containing granulated rubber and multiple geocell layers", Geotextiles and Geomembranes, 42(1), pp. 25-38 (2014).

15. Bathurst, R.J. and Jarret, P.M. "Large-scale model tests of geocomposite mattresses over peat subgrades", Transportation Research Record, 1188, pp. 28-36 (1988).

16. Dash, S.K., Krishnaswamy, N.R. and Rajagopal, K. "Bearing capacity of strip footings supported on geocell-reinforced sand", Geotextiles and Geomembranes, 19(4), pp. 235-256 (2001).

17. Sireesh, S., Sitharam, T.G. and Dash, S.K. "Bearing capacity of circular footing on geocell-sand mattress overlying clay bed with void", Geotextiles and Geomembranes, 27(2), pp. 89-98 (2009).

18. Madhavi Latha, G. and Somwanshi, A. "Effect of reinforcement form on the bearing capacity of square footings on sand", Geotextiles and Geomembranes, 27(4), pp. 409-422 (2009).

19. Moghaddas Tafreshi, S.N. and Dawson, A.R. "Comparison of bearing capacity of a strip footing on sand with geocell and with planar forms of geotextile reinforcement", Geotextiles and Geomembranes, 28(1), pp. 72-84 (2010).

20. Pokharel, S.K., Han, J., Leshchinsky, D., Parsons, R.L. and Halahmi, I. "Investigation of factors influencing behavior of single geocell-reinforced bases under static loading", Geotextiles and Geomembranes, 28(6), pp. 570-578 (2010).

21. Dash, S.K. "Influence of relative density of soil on performance of geocell-reinforced sand foundations", Journal of Materials in Civil Engineering, ASCE, 22(5), pp. 553-538 (2010).

22. Dash, S.K. "Effect of geocell type on load carrying mechanism of geocell reinforced sand foundations", International Journal of Geomechanics, ASCE, 12(5), pp. 537-548 (2012).

23. Biswas ,A., Murali Krishna, A. and Dash, S.K. "Influence of subgrade strength on the performance of geocell-reinforced foundation systems", Geosynthetics International, 20(6), pp. 376-388 (2013).

24. Mitchell, J.K., Kao, T.C. and Kavazanjian, E. "Analysis of grid cell reinforced pavement bases", Technical Report GL-79-8, Department of Civil Engineering, University of California, Berkeley, CA (1979).

25. Avesani Neto, J.O., Bueno, B.S. and Futai, M.M. "A bearing capacity calculation method for soil reinforced with a geocell", Geosynthetics International, 20(3) pp. 129-142 (2013).

26. Moghaddas Tafreshi, S.N., Shaghaghi, T., Tavakoli Mehrjardi, GH., Dawson, A.R. and Ghadrdan, M. "A simplified method for predicting the settlement of circular footings on multi layered geocell-reinforced non-cohesive soils", Geotextiles and Geomembranes, 43(4), pp. 332-344 (2015).

27. Kargar, M. and Mir Mohammad Hosseini, S.M. "Earth pressure distribution behind rigid non-yielding walls under the effect of repeated loading on backfill", Arabian Journal of Geosciences, 8(2), pp. 839-847 (2015).

28. Moghaddas Tafreshi, S.N. and Dawson, A.R. "A comparison of static and cyclic loading responses of foundations on geocell-reinforced sand", Geotextiles and Geomembranes, 32(5), pp. 55-68 (2012). 
29. Dash, S.K., Rajagopal, K. and Krishnaswamy, N.R. "Behavior of geocell-reinforced sand beds under strip loading", Canadian Geotechnical Journal, 44(7), pp. 905-916 (2007).

30. Gurbuz, A. and Mertol, H.C. "Interaction between assembled 3-D honeycomb cells produced from high density polyethylene and a cohesionless soil", Journal of Reinforced Plastics and Composites, 31(12), pp. 828-836 (2012).

31. Fakher, A. and Jones, C. "Discussion on bearing capacity of rectangular footings on geogrid-reinforced sand, by Yetimoglu T., Wu, J.T.H., Saglamer, A.,1994", Journal of Geotechnical Engineering, ASCE, 122(4), pp. 326-327 (1996).

32. Viswanadham, B.V.S. and Konig, D. "Studies on scaling and instrumentation of a geogrid", Geotextiles and Geomembranes, 22(5), pp. 307-328 (2004).

\section{Biographies}

Mohsen Kargar obtained his BSc, MSc and $\mathrm{PhD}$ degrees in Civil-Geotechnical Engineering from Amirkabir University of Technology. He is currently Assistant Professor of Civil Engineering at Shiraz Azad University. His research interests include soil improvement using geosynthetics and tunnel engineering with focus on dynamic behavior.

Seyyed Majdeddin Mir Mohammad Hosseini is a Professor of Geotechnical Engineering in Amirkabir University of Technology. He received his PhD (1988) from University of Leeds and his MSc (1977) from Tehran University. His main research interests are soil dynamics and geotechnical earthquake engineering with focus on laboratory works. 